\title{
Adipose Tissue Thymidine Kinase Activity in Man
}

\author{
DAVID BAUM, REBECCA Q. BECK, LAWRENCE D. HAMMER, JO ANNE BRASEL, AND \\ M. R. C. GREENWOOD \\ Department of Pediatrics, Stanford University Medical Center, Stanford, California; Department of Pediatrics, \\ Harbor-UCLA Medical Center, Torrance, California; and Department of Biology, Vassar College, \\ Poughkeepsie, New York
}

\begin{abstract}
Thymidine kinase activity was studied during human adipose tissue development. Adipose tissue was obtained from the groin in 81 persons, aged 7 wk through $60 \mathrm{yr}$. None had a metabolic or growth disorder. Adipose tissue thymidine kinase activity was highest in infants and lowest in adults. Peak thymidine kinase activity was seen in the early postnatal period and a lesser elevation was found in the preadolescent years, coinciding with hypothesized periods of proliferation of preadipocytes in man. In contrast, during adulthood, a time of stable lipid-laden cell number, thymidine kinase activity was lower. Although these adipose tissue samples include both stromal and fat cells, the data support the hypothesis that adipose tissue growth in early infancy is primarily the result of cellular proliferation, and that little cellular proliferation occurs after infancy, except possibly for a brief period prior to adolescence. (Pediatr Res 20: 118-121, 1986)
\end{abstract}

Study of the postnatal pattern of adipose tissue growth and development in man has been limited by the lack of a morphological or biochemical "marker" for preadipocytes $(1-12)$. The detection of lipid-containing cells can be accomplished with considerable accuracy using several cell counting techniques; however, preadipocytes and differentiating fat cells with little or no lipid remain undetected. Developmental studies of human fat cell accretion use data consisting of "fat cell number" and "cellular lipid content" which are derived from lipid-laden adipocytes only, and thus have limited value in assessing adipose tissue growth potential. This is of special methodological importance in the study of infants and children in whom it has been proposed that proliferation, rather than hypertrophy, predominates $(1,12)$.

Thymidine kinase (EC 2.7.1.21) catalyzes the phosphorylation of thymidine and plays a key role in DNA synthesis. Therefore, the enzyme is considered a useful index of cellular proliferation in growing tissues. Animal studies which include measurement of radiolabeled thymidine incorporation into DNA have shown that thymidine kinase activity is reliable for determining the rate of cellular proliferation in brain (13), liver (14), and adipose tissue $(3,15,16)$. In fact, the adipose tissue enzyme's activity correlated well with cellular proliferation in both normal and abnormal tissue growth. The kinase's pattern of change resembled the pattern of $\left[{ }^{3} \mathrm{H}\right]$ thymidine incorporation into fat cell DNA in the normally fed Sprague-Dawley rat $(3,15)$. Further-

Received May 1. 1985: accepted Scptember 16, 1985.

Correspondence and reprints David Baum, M.D., Department of Pediatrics, Stanford University Medical Center, Stanford, CA 94305.

Supported by American Heart Association Grant 84-751 and National Institutes of Health Grants HD-15394 and HD-72637. more, it was found to be temporally related to adipose tissue DNA and adipocyte accrual in the lean and genetically obese Zucker rat (17). The need for an index of cellular proliferation in human adipose tissue and the reliability of thymidine kinase activity for this purpose in animals prompted a study of this enzyme in man.

The purpose of this study was to characterize the developmental pattern of postnatal human adipose tissue thymidine kinase activity and to relate changes in this activity to age, body fat, lipid-containing adipocyte number, cellular lipid content, and body mass index.

\section{SUBJECTS AND METHODS}

Eighty-one patients without evidence of nutritional, metabolic, or chromosomal disorders were the subjects of this investigation. Adiposity was estimated by body mass index (18) in persons greater than $6 \mathrm{yr}$ and by weight for height for age in those less than $6 \mathrm{yr}$ of age (19). Using these criteria, all patients studied fell between the 5th and 95th percentile for the general population. Fifty-seven were male and 24 were female. Fifty-eight were Caucasian, nine black, five Hispanic, three Oriental and six designated "other." Thirty-three had completely asymptomatic heart disease without congestive heart failure or hypoxemia while 48 had no cardiovascular disorder.

Subcutaneous adipose tissue specimens (60-100 mg) were obtained via incisions made for routine medical management. Fat was taken from the groin at herniorrhaphy, orchiopexy, or cardiac catheterization. Tissue specimens were divided into two parts. Thymidine kinase activity was measured in one and cellular lipid content (cell size) was determined in the other.

That portion of tissue for enzyme determination was weighed and homogenized in $1 \mathrm{mM}$ 2-mercaptoethanol. Tissue homogenates of $5-30 \%$ (weight/volume) were prepared. After centrifugation at $4^{\circ} \mathrm{C}$, a small amount of infranatant was used for measuring thymidine kinase activity utilizing the Ledinko (20) modification of the method of Epstein et al. (16). Protein content of the enzyme fraction was measured by the Coomassie Blue method (21). Cellular lipid content was determined on the second portion of the fat sample by the osmium fixation method (22). Total lipid-laden cell number was calculated by dividing total body fat by the specimen's average cellular lipid content. Between the ages of 2 and $14.5 \mathrm{yr}$, total body fat was calculated using the derived equation of Friis-Hansen (23). Total body fat was measured by hydrostatic weighing in subjects older than $14.5 \mathrm{yr}(24)$. Total body fat was not determined for individuals less than $2 \mathrm{yr}$ of age since a reliable and acceptable method for this age group is lacking. Measurement of height and weight was performed and body mass index was calculated (weight/height ${ }^{2}$ ).

We analyzed the relationship between thymidine kinase activity on the one hand, and age, body mass index, cellular lipid content, and lipid-laden cell number on the other. 
The procedures followed in this investigation were in accord with the ethical standards of the Stanford University Committee for the Protection of Human Subjects in Research.

\section{STATISTICAL METHODS}

Analysis of variance was used to assess overall differences between age-group means. Scheffe's test of multiple contrasts was used for pairwise comparison of age-group means if the analysis of variance revealed a significant between-group difference (25). Spearman correlations and multiple linear regression were used to analyze the relationships between thymidine kinase activity and age, measures of body fatness, lipid-laden cell number, and cellular lipid content. Spearman correlations, rather than product moment correlations, were used due to the nonnormal distribution of the data. $p$ values of less than 0.05 were considered significant. All analyses were performed using the Statistical Analysis System (26).

Comparison of subjects with asymptomatic heart disease and subjects without heart disease revealed no significant differences in adipose tissue thymidine kinase activity, total body fat, cellular lipid content, total number of lipid-containing cells, height, weight, or body mass index. Therefore, the data from the two groups were combined for further analyses.

\section{RESULTS}

Thymidine kinase. Thymidine kinase activity was found to vary with age. For the purpose of clarity of presentation, values of thymidine kinase activity, expressed as cpm per mg protein, were grouped into five age-related phases, as shown in Figure 1. These age ranges were based upon stages of adipose tissue growth found in man (27). Our age-related subject groups are characterized in Table 1 by number, and mean height, weight, and body mass index. Thymidine kinase activity was highest in subjects less than 9 months of age. The enzyme's activity was lower in subsequent years until just prior to adolescence (ages 9-13.9 yr) when thymdine kinase activity tended to rise. The lowest levels of thymidine kinase activity were seen in individuals $20 \mathrm{yr}$ of age and older. Overall differences in thymidine kinase activity between age groups were analysed using analysis of variance and were found significantly different $(p<0.0003)$. The difference between children less than 9 months and the group aged 0.75 to $8.9 \mathrm{yr}$ was striking (Fig. 1) and significant by Scheffe's test. Children 9-13.9 yr had greater thymidine kinase activity than children 0.75-8.9 yr and individuals older than $20 \mathrm{yr}$ of age. However, the difference was not statistically significant by



Fig. 1. Thymidine kinase activity and age. Means and SEs are shown. Overall differences in thymidine kinase activity between age groups were analyzed using analysis of variance $\left(\mathrm{F}_{4,76}=5.93: p<0.0003\right)$.
Table 1. Human subject groups

\begin{tabular}{|c|c|c|c|c|c|}
\hline $\begin{array}{c}\text { Age group } \\
(\mathrm{yr})\end{array}$ & Gender & $n$ & $\begin{array}{c}\text { Mean } \\
\text { ht } \\
(\mathrm{cm})\end{array}$ & $\begin{array}{c}\text { Mean } \\
w t \\
(\mathrm{~kg}) \\
\end{array}$ & $\begin{array}{c}\text { Mean body } \\
\text { mass index } \\
\left(\mathrm{kg} / \mathrm{m}^{2}\right)\end{array}$ \\
\hline \multirow[t]{2}{*}{$0-0.74$} & Male & 9 & 60.6 & 5.8 & 15.0 \\
\hline & Female & 1 & 51.0 & 3.7 & 14.0 \\
\hline \multirow[t]{2}{*}{$0.75-8.9$} & Male & 28 & 103.9 & 17.9 & 15.7 \\
\hline & Female & 10 & 96.9 & 15.2 & 15.4 \\
\hline \multirow[t]{2}{*}{$9-13.9$} & Male & 10 & 147.0 & 40.0 & 17.9 \\
\hline & Female & 5 & 148.7 & 43.0 & 19.0 \\
\hline \multirow[t]{2}{*}{$14-19.9$} & Male & 7 & 174.3 & 67.0 & 21.4 \\
\hline & Female & 3 & 153.3 & 54.9 & 22.7 \\
\hline \multirow[t]{2}{*}{$20+$} & Male & 3 & 172.5 & 79.4 & 26.0 \\
\hline & Female & 5 & 164.0 & 63.1 & 23.2 \\
\hline
\end{tabular}



Fig. 2. Thymidine kinase activity, cell lipid content, and fat cell number according to age. Means and SEs are shown. For this comparison, the age range of the two youngest age groups was modified because there were no estimates of adipose tissue mass. Therefore, lipid-laden cell number was not available before $2 \mathrm{yr}$ of age. The two resulting groups were aged $0-1.9 \mathrm{yr}(n=17)$ and $2-8.9 \mathrm{yr}(n=31)$,

Scheffé's test. Overall, there was not a significant difference in thymidine kinase activity between the sexes. Similarly, no differences were noted in Caucasians, blacks, Hispanics, or Orientals.

Upon considering data obtained between ages 2 through 60 $\mathrm{yr}$, there was no significant correlation of thymidine kinase activity with age, body fat, lipid-laden cell number, cell lipid content, or body mass index. A graphic comparison of thymidine kinase activity, and cell size and number is shown in Figure 2. Since adipose tissue mass and cell number cannot be reliably determined before $2 \mathrm{yr}$ of age, the grouping of subjects by age was modified for these analyses and for the graphic comparison in Figure 2.

Total body fat. Total body fat increased from $1-2 \mathrm{~kg}$ at age 2 yr to $15-18 \mathrm{~kg}$ at $16 \mathrm{yr}$. Between $16 \mathrm{yr}$ and adulthood there was little further increase seen in total body fat. These findings are in agreement with previously published data $(6,10,11)$.

Cellular lipid content. In the 1 st yr of life, fat cell size ranged from 0.06 to $0.24 \mu \mathrm{g}$ lipid/cell. A negligible increase in cell lipid content occurred until ages 9-10 yr, when enlargement took 
place at a more rapid rate. Enlargement continued until 14-20 $\mathrm{yr}$ of age, after which cell size varied widely. In adults the range of cellular lipid content was from 0.40 to $0.75 \mu \mathrm{g} / \mathrm{cell}$, values comparable to previously published data $(6,10,11)$.

Lipid-laden cell number. Total number of lipid-laden cells was determined for subjects $2 \mathrm{yr}$ of age and older. At age $2 \mathrm{yr}$, cell number was approximately 1 billion. The number of detectable fat cells increased slowly until 9-10 yr of age. Subsequently, the rate of increase accelerated until age $16 \mathrm{yr}$, after which the number of fat cells appeared to plateau in a range between 26 and 76 billion. This range in adults is comparable to previously reported data $(6,10,11)$.

\section{DISCUSSION}

These data demonstrate age-related variation in human adipose tissue thymidine kinase activity. The changes in activity are of interest in relation to age-related changes in human lipidladen cell size and number. Since thymidine kinase activity is considered a reliable index of cellular replication in laboratory animals (15-17), it is of note that the high enzyme activity seen here in infancy corresponds to a major period in a) human adipose tissue growth and b) increased adipocyte number as measured by fat cell counting and sizing techniques $(1,2,4,9$, 12). If both preadipocytes and stromal cells participate in this growth as believed, our thymidine kinase activity data suggest that proliferation, rather than recruitment of previously differentiated nonlipid containing cells, may be occurring during early infancy. Peak thymidine kinase activity coincides with the high rate of increase in lipid-laden cell number said to occur during the perinatal period (1). Furthermore, between infancy and adolescence, thymidine kinase activity is low, yet total body fat increases in conjunction with increasing cell size and number, suggesting that the mechanisms of adipose tissue growth after infancy may shift from proliferation to filling of nonlipid containing cells. An upward trend of thymidine kinase activity prior to adolescence corresponds to another period of accelerated adipose tissue growth and increasing fat cell number $(1,9)$, suggesting some renewed cellular proliferation. After adolescence, cellular enlargement via lipid filling may be the predominant mechanism of adipose tissue growth since thymidine kinase activity seems to fall despite a continued increase in lipidcontaining cell number. Such a pattern of tissue growth with hyperplasia, followed by hyperplasia plus hypertrophy, and then by hypertrophy alone, is seen in other nonregenerating tissues (28).

In adult man, the stabilization of lipid containing cell number and the constant low level of thymidine kinase activity imply a continued low rate of cellular replication. This low activity in adult man may relate to turnover of nonadipocyte cells in the tissue, such as endothelial cells. In fact, it is likely that some basal level of thymidine kinase activity is present at all ages due to proliferation and/or turnover of cells of the supporting structure in adipose tissue. In addition, it is possible that continued fat cell turnover may make accelerated cellular replication possible in adult man, as it does in the adult rat exposed to high caloric intake (29).

Since adipose tissue contains both adipocytes and stromal cells, one must be cautious in relating thymidine kinase activity from adipose tissue samples to adipocytes alone. Low levels of enzyme activity reliably signify low rates of proliferation of all cell types, including adipocytes. Higher levels of activity may reflect increased proliferation of either adipocytes or stromal cells. However, developmental animal data suggest that the higher levels of thymidine kinase activity in early life are more likely to be related to fat cell proliferation $(15,17)$.

Realizing that there is regional variation in human cell lipid content (1), only one site was used for tissue sampling in this investigation. The groin was chosen because of a) tissue availa- bility via incisions made for regular medical management and b) prior studies from our laboratory suggesting that the developmental pattern of cellular lipid content in the groin was similar to the published data obtained from buttock fat (9). Although the sequence of change in cell size and calculated number of lipid-laden cells were generally similar in groin- and buttockrelated data, this investigation demonstrated some differences. In younger patients $(2-8.9 \mathrm{yr})$, fat cells from the groin were smaller and the derived total cell number was larger than comparable values determined from buttock specimens. These observations suggest that site-related differences in adipose tissue thymidine kinase activity may exist as well.

Thymidine kinase activity can be measured in small biopsy samples taken percutaneously or at surgery. In turn, it is hoped that longitudinal studies can be performed to confirm our findings and to assess individual trends and variability in thymidine kinase activity in the groin and other adipose tissue sites.

Acknowledgments. Our thanks to Drs. Paul T. Pitlick, James W. French, Stephen Schocat, Gary Hartman, Duncan Govan, Fuad S. Freiha and Robert Kessler for obtaining adipose tissue specimens. The technical assistance of Christine A. Warren, Grace Chow, Barbara Frey-Hewitt and Diana Blase is appreciated. Our gratitude to Winifred Noble for excellent secretarial assistance.

\section{REFERENCES}

1. Bonnet FP, Rocour-Brumioul D 1981 Normal growth of human adipose tissue. In: Bonnet FP (ed) Adipose Tissue in Childhood. CRC Press Boca Raton, FL, pp 81-107

2. Brook CGD 1972 Evidence for a sensitive period in adipose cell replication in man. Lancet 2:624-627

3. Greenwood MRC. Hirsch J 1974 Postnatal development of adipocytc cellularity in the normal rat. $J$ Lipid Res 15:474-483

4. Hager A. Sjostrom L, Arvidson B, Bjorntorp P. Smith V 1977 Body fat and adipose tissue cellularity in infants: a longitudinal study. Metabolism 26:607614

5. Hirsch J, Han PW 1969 Cellularity of rat adipose tissue: effects of growth. starvation and obesity. J Lipid Res 10:77-82

6. Hirsch J, Knittle JL 1970 The cellularity of obese human adipose tissue. Fed Proc 29:1516-1521

7. Johnson PR, Hirsch J 1972 Cellularity of adipose depots in six strains of genetically obese mice. J Lipid Res 13:2-11

8. Knittle JL, Hirsch J 1968 Effect of early nutrition on the development of rat epididymal fat pads: cellularity and metabolism. J Clin Invest 47:2091-2098

9. Knittle JL, Timmers K, Ginsberg-Felner F, Brown RE, Katz DF 1979 The growth of adipose tissue in children and adolescents. J Clin Invest 63:239246

10. Salans LB, Cushman SW, Weisman RE 1973 Studies of human adipose tissue: adipose cell size and number in non-obese and obese patients. J Clin Invest 52:929-941

11. Sjostrom S, Bjorntorp P 1974 Body composition and adipose tissue cellularity in obesity. Acta Med Scand 195:201-211

12. Stern JS, Greenwood MRC 1974 A review of development of adipose cellularity in man and animals. Fed Proc 33:1952-1955

13. Yamagami S, Mori K. Kawakita Y 1972 Changes of thymidine kinase in the developing rat brain. J Neurochem 19:369-376

14. Adelstein SJ, Baldwin C. Kohn HI 1971 Thymidine kinase in mouse liver: Variations in soluble and mitochondrial-associated activity that are dependent on age, regeneration, starvation, and treatment with actinomycin $D$ and puromycin. Dev Biol 26:537-546

15. Cleary MP, Klein BE, Brasel JA. Greenwood MRC 1979 Thymidine kinase and DNA polymerase activity during postnatal growth of the epididymal fat pad. J Nutr 109:48-54

16. Epstein S. Esanu C. Raben MS 1969 The effect of growth hormone and cortisone on thymidine kinase activity in rat adipose tissue. Biochem Biophys Acta 186:280-285

17. Cleary MP. Brasel JA, Greenwood MRC 1979 Developmental changes in thymidine kinase. DNA and fat cellularity in Zucker rats. Am J Physiol 236:E508-E513

18. Cronk CE, Roche AF 1982 Race and sex-specific reference data for triceps and subscapular skinfolds and weight/stature. Am J Clin Nutr 35:347-354

19. Hamill PVV, Drizd TA, Johnson Cl, Reed RB, Roches AF. Moore W 1979 Physical growth: National Center for Health Statistics percentiles. Am J Clin Nutr 32:607-629

20. Ledinko 1967 Stimulation of DNA synthesis and thymidine kinase activity in human embryonic kidney cells infected by adenovirus 2 or 12 . Cancer Res 27:1459-1469 
21. Bio-Rad Protein Assay 1979 Bio-Rad Laboratories, Richmond. CA

22. Hirsch J, Gallian E 1968 Methods for the determination of adipose tissue cell size in man and animals. J Lipid Res 9:110-119

23. Friis-Hansen B 1961 Body water compartments in children: changes during growth and related changes in body composition Pediatrics 28:169-18

24. Siry WE 1956 Gross composition of the body. In: Lawrence JH. Tobias CA (eds) Advances in Biological Medical Physics. Academic Press, New York. pp 239-280

25. Zar JH 1984 Biostatistical Analysis. Prentice Hall Inc, Englewood Cliffs, NJ pp 196-198

26. SAS Users Guide 1982 Statistics. SAS Institute, Cary, NC

27. Rolland-Cachera MF. Sempe M, Guilloud-Bataille M, Patois E. PequignotGuggenbuhl F. Fautrad V 1982 Adiposity indices in children. Am J Clin Nutr 36:178-184

28. Winick M. Noble A 1965 Quantitative changes in DNA. RNA and protein during prenatal and postnatal growth in the rat. Dev Biol 12:451-466

29. Faust IM, Johnson PR. Stern JS, Hirsch J 1978 Diet-induced adipocyte number increase in adult rats: a new model of obesity. Am J Physiol 235:E279-E286 